\title{
The Influence of Income, Social Capital, and Participation in Farmer Group on the Sustainability of Vegetable Farmers Business in Selo Village Selo Sub-district Boyolali Regency
}

\author{
Empratikta Zulpicha \\ Sociology Department, \\ Universitas Sebelas Maret, Surakarta, Indonesia \\ Yulius Slamet \\ Sociology Department, \\ Universitas Sebelas Maret, Surakarta, Indonesia \\ Mahendra Wijaya \\ Sociology Department, \\ Universitas Sebelas Maret, Surakarta, Indonesia
}

\begin{abstract}
This study aimed to explain how much income and social capital influenced the sustainability of vegetable farmer businesses in Selo Village, Selo District, Boyolali Regency. This study used quantitative research with survey methods. The population in this study was 584, thus the samples that taken were 123 respondents with $8 \%$ error rate. The researchers got the sources of data from the results of questionnaires which were distributed to vegetable farmers in Selo village and supported by data from the Selo village. Questionnaires used as data collection techniques and multiple linear regression analysis used as data analysis techniques in this study. The results of this study showed that there is an influence of income and social capital on business continuity. It was known that the significance value of the income variable (X1) was 0,000 and social capital (X2) was 0,000 . It can be concluded that income variables (X1) and social capital (X2) significantly influenced the business continuity variable (Y) because the significance value is smaller than 0.05 . The value of $R 2$ or $R$ Square is 0.225 , this indicated that the contribution of the influence of $\mathrm{X} 1$ and $\mathrm{X} 2$ on $\mathrm{Y}$ is $22.5 \%$ while the remaining $77.5 \%$ is the contribution of other variables which were not examined.
\end{abstract}

Keywords: Social capital; Business sustainability; Farmer group; Vegetable farmers

\section{INTRODUCTION}

Indonesia is an agrarian country, which has abundant natural wealth located in a very strategic position. In terms of geography, Indonesia is in the tropics area which has high rainfall. It is supported many types of plants can grow easily. In line with this, the majority of the populations make a living as farmers, which is equal to 88.50 percent of the total population of Indonesia who works (BPS, 2017). As well as Central Java that became the location of this study. From the total population of Central Java who works, 92.29 percent work in the agricultural sector (BPS, 2017). Based on these data, it shows that the amount of labor absorbed is dominated by the agricultural sector.

The agricultural sector in Indonesia is largely built by farmers so the government needs to pay attention to the welfare of farmers. The thing to be noticed is the farmers' life pattern. That 
pattern is very influential on the culture and structure in the community and can determine the level of prosperity and welfare of farmers. In solving problems that exist within a community or society, cultural and structural factors are often used as a reference for social capital. According to Fukuyama (1995) social capital is a capability that arises from general trust in a society or in certain parts of it. Social capital refers to the relationship of trust, togetherness, and exchange, shared rules and norms, linkages and networks within the community allow each member of the community to take collective action and secure other important resources.

With the social capital owned by vegetable farmers in Selo Village, the amount of vegetable production reaches a considerable number. With a large amount of production, it will be directly proportional to a large amount of income. Running a vegetable business cannot be separated from challenges and constraints, as a solution, the social capital is needed so that it can survive and continue the vegetable business in Selo Village. But the existence of these constraints does not make vegetable farmers close the vegetable business or switch jobs but conversely, the vegetable farmers in Selo Boyolali Village still maintain the vegetable business. The following are the population in Selo Village who work as farmers:

Table 1. The Number of Population in Selo Village who Work as Farmers

\begin{tabular}{|c|c|c|}
\hline Hamlet & The year 2017 & The year 2018 \\
\hline Gebyok & 257 & 257 \\
\hline Selo & 183 & 183 \\
\hline Senet & 130 & 130 \\
\hline Spandan & 260 & 260 \\
\hline Total & 830 & 830 \\
\hline
\end{tabular}

Source: Riyanto, 2018

Based on the table above it can be concluded that vegetable farmers in Selo village still maintain vegetable business in addition to the many factors and obstacles in maintaining the business. It can be seen that the population in Selo village works as a farmer from 2017 and 2018 with the same number, those are 830 people.

With these conditions, the majority of the people are incorporated into farmer groups. Through the activities of farmer groups, farmers can easily develop the vegetable business that they have been running, because basically, the farmer groups aim to prosper the group members. Farmers in Selo village share information regarding planting vegetables, seeds, and fertilizers. The following are the number of farmer groups in Selo village.

Table 2. The Number of Farmer Group in Selo Village

\begin{tabular}{|c|c|c|c|}
\hline \multirow{2}{*}{ Village } & Hamlet & $\begin{array}{c}\text { The Number } \\
\text { of Farmer group }\end{array}$ & $\begin{array}{c}\text { The Number } \\
\text { of Farmer Group Member }\end{array}$ \\
\hline \multirow{3}{*}{ Selo } & Gebyok & 6 & 124 \\
\cline { 2 - 4 } & Selo & 6 & 120 \\
\cline { 2 - 4 } & Senet & 4 & 80 \\
\cline { 2 - 4 } & Spandan & 13 & 260 \\
\hline \multicolumn{2}{|c|}{ Total } & 29 & 584 \\
\hline
\end{tabular}

Farmer Group Association (GAPOKTAN) of Selo, 2017

Based on the table above, there are 29 farmer groups with 584 members. Every year there is an increase in the number of farmer groups in Selo village. Basically, farmer groups are a forum for vegetable farmers in Seo Village to get information about vegetables. The aim of the farmer group is to prosper the group members so that the existence of a farmer group can expand the social network owned by vegetable farmers in Selo Village so that they can maintain their 
vegetable business. This is the background of the author to examine the influence of income and social capital on the sustainability of vegetable farmer businesses in Selo Village, Selo District, Boyolali Regency.

\section{Research Type}

\section{RESEARCH METHODOLOGY}

Quantitative research with survey method was used as the type of this research. Quantitative research emphasizes more on numerical data that is processed by statistics and survey research is research whose data is collected from samples or respondents to the population using questionnaires or interviews.

\section{Research Setting}

This research was conducted in Selo Village, Selo District, Boyolali Regency. The basis for determining the location of the study were: 1) The majority of the people work as farmers, 2) Farmers in Selo Village maintain vegetable business although there are many vegetable competitors in Boyolali, 3) The role of farmer groups in maintaining vegetable businesses in Selo Village, and 4) Besides the high price of fertilizers, pesticides, and production tools for planting vegetables, vegetable farmers in Selo Village maintain their business. This research was conducted in March 2019.

\section{Population and Sample}

The populations of this research were 584 vegetable farmers in Selo village who joined the farmer group. Then 123 people were taken as the sample of the research. The samples were taken using Slovin technique with $8 \%$ failure level.

\section{Research Variables and Operational Definition}

Income (X1) is the result of the combination of labor, capital, and services in the field of management. This farmer's income consists of a portion of the gross income used in farming (Hadisapoetro, 1973 in Handayani, 2005: 39). Income is measured based on the amount of income generated from the sale of public income. Social capital (X2) is a network that has values and social contacts that affect the productivity of individuals and groups. Social capital is measured by the network, norm of trust, reciprocity, and information sharing. While business sustainability (Y) is a condition or business condition in which there are ways to maintain develop, and protect resources and meet existing needs in the business. Business sustainability is measured based on business sustainability based on capital, business sustainability based on agricultural products, business sustainability based on human resources, and business sustainability based on marketing.

\section{Data Collection Technique}

The data collected in this study consisted of primary data and secondary data. Primary data was data obtained from distributing questionnaires to vegetable farmers in Selo Village, while secondary data was data obtained from relevant institutions or agencies such as village head offices, Central Statistics Agency (BPS) and others related to this research.

\section{Data Analysis Technique}

The technique used to analyze the data was a multiple linear regression technique. 


\section{FINDINGS AND DISCUSSION}

\section{The Influence of Income on the Sustainability of Vegetable Farmers Business in Selo} Village, Selo Sub-district, Boyolali Regency

The findings from the testing of income regression on business sustainability showed that the significance value of the income variable (X1) is 0.001 , it can be concluded that the income variable (X1) significantly influenced the business sustainability variable (Y) because the significance value is less than 0.05 . The value of $\mathrm{R} 2$ or $\mathrm{R}$ Square is 0.083 , this indicated that the contribution of the influence of $\mathrm{X} 1$ to $\mathrm{Y}$ is $8.3 \%$ while the remaining $91.7 \%$ is the contribution of other variables not examined. High income will affect vegetable business, as well as low income will also affect the vegetable business in Selo Village. This has affected vegetable farmers while maintaining their vegetable business to date.

\section{The Influence of Social Capital on the Sustainability of Vegetable Farmers Business in Selo Village, Selo Sub-district, Boyolali Regency}

The test from social capital regression on business sustainability showed that the significance value of the social capital variable (X2) is 0,000 , it can be concluded that the social capital variable (X2) significantly influenced the business sustainability variable (Y) because the significance value is less than 0 05. The value of R2 or R Square found in the Model Summary table is 0.128 , this indicated that the contribution of the influence of $\mathrm{X} 2$ to $\mathrm{Y}$ is $12.8 \%$ while the remaining $87.2 \%$ is the contribution of other non-examined variables. Then it can be said that social capital is very important for business sustainability. The more vegetable farmers in Selo Village have a high social network, the opportunity for business success will be because the more information obtained about vegetables and the easier the farmers sell vegetables through social networks owned.

\section{The Influence of Income and Social Capital on the Sustainability of Vegetable Farmers Business in Selo Village, Selo Sub-district, Boyolali Regency}

From the testing results of the regression of income and social capital on business sustainability it is known that the significance value of income variable (X1) is 0,000 and social capital (X2) is 0,000 , it can be concluded that the income variable (X1) and social capital (X2) significantly influence the business sustainability variable (Y) because the significance value is smaller than 0.05 . The value of R2 or R Square is 0.225 , this indicated that the contribution of the influence of $\mathrm{X} 1$ and $\mathrm{X} 2$ on $\mathrm{Y}$ is $22.5 \%$ while the remaining $77.5 \%$ is the contribution of other non-examined variables.

The following is the Regression diagram of the influence of Income and social capital on the sustainability of vegetable businesses

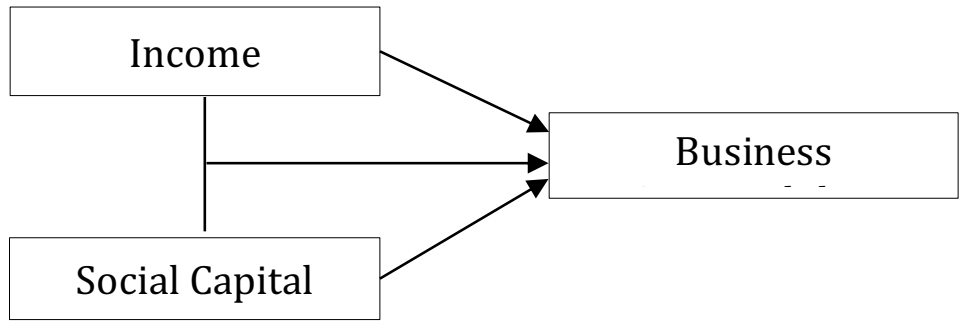

Figure 1. Regression Diagram of Income and Social Capital for Business Sustainability

\section{Theoretical Analysis}

The theory used in this study is the theory of social status and social capital theory. The theory of social capital is a social relationship between a group of individuals and families that form a social group including good intentions, a sense of friendship, mutual sympathy and 
cooperation (Hanifan, 1916: 130). Bourdieu defines social capital as the beginning of the formation of a network so as to produce relationships between individuals in society. Relationships that have occurred and perpetuated continuously will lead to mutual recognition between these individuals. In his writing, Bourdieu distinguishes the notion of social capital as consisting of economic capital (economic capital), cultural capital (culture capital) and social capital (social capital). Economic capital is capital that can be converted into money and in the form of ownership. While cultural capital is the academic achievement of individuals. Pierre Bourdieu's concept of social capital shows that there are interdependencies between various types of other capital resources and as embedded in economic capital (Edwards, in Slamet, 2011: 12).

In this study vegetable farmers in the Selo village interacted and cooperated in a system. The vegetable business in Selo Village continues because of a system that supports it from behind. The results of this study showed that the system came from farmer groups. The role of farmer groups in Selo Village greatly influenced the sustainability of vegetable businesses. This research showed that social capital, namely social networks, trust, reciprocity and sharing information could support the sustainability of vegetable farmers in Selo village. In analyzing social capital in vegetable farmers in Selo village, the vegetable business in Selo village is still based on 1) the vast social network owned by farmers to maintain vegetable business, 2) trust held by farmers towards fellow vegetable farmers, middlemen, and local farmer groups, 3) reciprocity between vegetable farmers, middlemen and farmer groups, and 4) sharing information related to vegetable planting.

It can be concluded that the wider the social network owned by vegetable farmers, the easier it is to develop a vegetable business. Conversely, if the narrower social network owned by vegetable farmers, the more possible the business continuity will be narrower. The establishment of social networks between individuals or individuals with groups and the existence of continuous interaction will emerge in trust. The existence of trust results in the attitude of helping each other and sharing information about vegetables.

Vegetable farmers in Selo village view farmer groups as a means to obtain material benefits or other personal benefits so that an increase in income is based on farmers' knowledge of vegetables through farmer groups. Based on the results of the research in Selo Village, it was found that of the 123 respondents surveyed some said that there was an increase in agricultural yields but some said that there was a decline in agricultural yields because the prices of vegetables in the market were declining because some vegetables were experiencing price declines. This happens because of the many yields of certain types of vegetables, with abundant yields, the price of these vegetable decreases and ultimately the income earned also decreases.

The high yields obtained will affect the social status of farmers in the community. The higher the income, the more it affects its social status. Basically social status theory is produced based on the concept of social stratification. Understanding the concept of social stratification refers to grouping people into levels or strata in a hierarchy vertically. Social position (Soekanto, 2012: 210) is a person's place in general in his community with respect to other people, in the sense of his social environment, prestige, and rights and obligations.

\section{Conclusion}

\section{CONCLUSION AND SUGGESTIONS}

From the results of research that has been conducted on vegetable farmers in Selo Village, several conclusions can be drawn: 
- There is an influence of income on the sustainability of the vegetable farmers business in Selo Village, Selo Sub-District, Boyolali Regency, which is $8.3 \%$.

- There is an influence of social capital on the sustainability of vegetable farming businesses in Selo Village, Selo District, Boyolali Regency, which is $12.8 \%$.

- There is an influence of income and social capital on the sustainability of vegetable farmer businesses in Selo Village, Selo District, Boyolali Regency which is equal to $22.5 \%$.

\section{Suggestions}

The results of this study formulated several suggestions, as follows:

- For vegetable farmers, it is expected to be able to expand social networks, both with fellow farmers, local and outside village traders and to the agricultural service through the activities of farmer groups. Farmers are also expected to increase participation in farmer group activities so that programs from the government for the welfare of farmers, especially in Selo Village can be realized well.

- It is hoped that the agricultural service will provide support to vegetable farmers in Selo Village through farmer groups with agricultural programs and provide opportunities for agricultural training for vegetable farmers in Selo Village.

\section{References}

Fukuyama, Francis. (1995). Trust: The Social Virtues and the Creation of Prosperity. New York: The Free Press.

Handayani, Niken. (2007). Modal Sosial dan Keberlangsungan Usaha (Studi Deskriptif Kualitatif tentang Keterkaitan Hubungan Modal Sosial dengan Keberlangsungan usaha Pengusaha Batik di Kampung Kauman, Kelurahan Kauman, Kecamatan Pasar Kliwon, Surakarta). Surakarta: Universitas Sebelas Maret.

Hanifan, L.J. (1916). The Rural School Community Center. The Annals of the American Academy of Political and Social Science, 67: p. 130-138

Slamet, Yulius. (2011). Modal Sosial dan Kemiskinan. Surakarta: UNS Press.

Soekanto, Soejono. (2012). Sosiologi Suatu Pengantar. Jakarta: PT. RajaGrafindo Persada. 